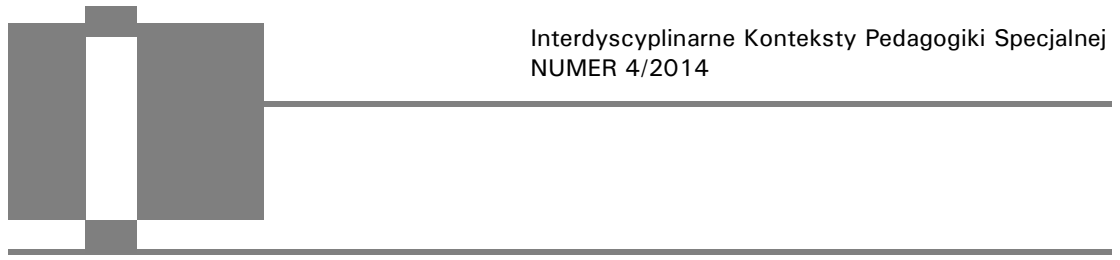

\title{
Recenzja książki Danuty Apanel pt. Teoria i praktyka kształcenia integracyjnego w Polsce w latach 1989-2012, Wydawnictwo Adam Marszałek, Toruń 2014
}

Jedną z najnowszych pozycji wydawniczych z pogranicza pedagogiki i pedagogiki specjalnej stanowi książka Danuty Apanel pt. Teoria i praktyka kształcenia integracyjnego w Polsce w latach 1989-2012. Autorka tego obszernego opracowania wykorzystała materiał empiryczny oraz bogaty zbiór bibliograficzny. Poruszyła wiele wątków, dzięki czemu jej publikację warto polecić osobom zajmującym się tematyką edukacji integracyjnej zarówno zawodowo, jak i naukowo. Książka ta powstała w wyniku długoletnich badań autorki nad kondycją oraz procesem kształtowania się szkolnictwa integracyjnego w naszym kraju. Przedmiotem analizy stało się szkolnictwo integracyjne na wszystkich etapach - od edukacji przedszkolnej po wyższą. Celem dociekań było zbadanie różnych aspektów przeobrażeń szkolnictwa integracyjnego - od architektonicznego dostosowania budynków szkolnych i rozwoju bazy dydaktycznej, poprzez tendencje wiążące się z liczbą uczniów uczestniczących w edukacji integracyjnej oraz zmian zachodzących $\mathrm{w}$ kształceniu studentów $\mathrm{z}$ niepełnosprawnością, aż po kwalifikacje kadry pedagogicznej i charakterystykę instytucji wspierających oświatowe działania integracyjne. Pozycja autorstwa Danuty Apanel wypełnia pewną lukę, jak dotąd bowiem powstało niewiele opracowań naukowych podejmujących historyczne aspekty kształcenia integracyjnego. Przy poruszaniu poszczególnych zagadnień autorka kieruje się zasadą: „od ogółu do szczegółu", która wyznacza strukturę poszczególnych rozdziałów. W pierwszej kolejności omawia aspekty o charakterze uniwersalnym i koncepcyjnym, a w dalszych częściach książki uszczegóławia je i przenosi na grunt polski. 
Praca składa się z pięciu rozdziałów. W pierwszym z nich zostały omówione geneza oraz rozwój różnych koncepcji integracyjnych w edukacji. Autorka przywołuje działalność, myśli i poglądy osób mających niebagatelny wpływ na rozwój pedagogiki jako nauki - powołuje się na takie nazwiska jak: Vives, Morus, Komeński, Pestalozzi, Séguin, Decroly, Joteyko, Montessori, Grzegorzewska, Freinet, Suchomiński, Korczak, Radlińska, Dega, Hulek. Elementem wspólnym dla tych wszystkich postaci jest postulat powszechnego i równego dostępu do edukacji, niezależnego od statusu materialnego czy kondycji psychofizycznej. Tym samym podkreślone zostaje to, że idee integracyjne nie są niczym nowym. Ich geneza sięga początków humanistyki - są one w niej głęboko zakorzenione.

Następnie autorka analizuje teoretyczne podstawy kształcenia integracyjnego, ze szczególnym uwzględnieniem elementarnych praw osób $\mathrm{z}$ niepełnosprawnością podkreślonych $\mathrm{w}$ międzynarodowych dokumentach oraz koncepcjach, które zyskały już status uniwersalnych i aktualnie wyznaczają kierunek kształtowania polityki w wielu państwach. Pojęcie „integracja” jest rozpatrywane w świetle teorii socjologicznych, które stały się bazą do rozważań na gruncie edukacyjnym. Poruszone zostały m.in. następujące wątki: mechanizmy stereotypizacji, koncepcja piętna Goffmana, egalitaryzm Bakera, normalizacja Nirjego. Analiza ta nie jest jednostronna - pod uwagę wzięto $\mathrm{w}$ niej również argumenty przeciwników integracji. Dzięki temu czytelnik może uzyskać całościowy i obiektywny obraz problemu. Kontynuacją oraz uzupełnieniem wątku socjologicznego jest prezentacja wyników badań własnych autorki nad postawami mieszkańców Słupska wobec osób z niepełnosprawnością.

Dalej zostały omówione zalety i słabe strony różnych systemów kształcenia osób z niepełnosprawnością. Umożliwia to pełniejszy wgląd w omawianą tematykę i możliwość dokonania porównań. Opisy poparto przykładami rozwiązań stosowanych w różnych krajach: w Niemczech, Anglii, Japonii i we Włoszech.

Rozdział drugi poświęcono aspektom psychomedycznym i prawnym niepełnosprawności. Zawarto $\mathrm{w}$ nim szczegółową charakterystykę poszczególnych rodzajów niepełnosprawności, wybranych zaburzeń psychicznych oraz rozwojowych. Ponadto autorka zestawiła statystyki dotyczące aspektów ilościowych poszczególnych jednostek klinicznych (dane GUS z lat 1989-2012). Przeanalizowała również międzynarodowe dokumenty stanowiące o prawach osób z niepełnosprawnością: Deklarację madrycką, Deklarację z Salamanki, Światową deklarację "Education for All”, 
konwencje praw dziecka, człowieka oraz osób niepełnosprawnych. W dalszej części książki zawęziła te aspekty do doświadczeń polskich.

W rozdziale trzecim uwzględniono analizę uregulowań prawnych dotyczących edukacji osób z niepełnosprawnością w strukturach szkolnictwa ogólnodostępnego na poziomie krajowym. Posłużyły do tego rozporządzenia MEN z lat 2001-2010.

W dalszej części opracowania przeanalizowano głównie materiał empiryczny uzyskany przez autorkę podczas badań kondycji polskiego kształcenia integracyjnego. Badania miały charakter ilościowy. Zostały przeprowadzone na podstawie danych dostarczonych przez kuratoria oświaty Ośrodkowi Rozwoju Edukacji w latach 2005-2012, analizy statystyk gromadzonych w GUS i ankiet przeprowadzonych przez autorkę w szkołach integracyjnych na terenie całego kraju. Autorka porównała sytuację w różnych województwach, co pozwala wskazać regiony, w których wciąż są potrzebne zmiany. Na początku sytuacja była badana w kontekście rozwoju infrastruktury szkolnej, głównie różnych dostosowań architektonicznych. Kolejny etap badań poświęcono opisowi specyfiki organizacji pracy w placówkach integracyjnych. Wyraźnie zarysowuje się tendencja do wzrostu liczby dzieci i młodzieży $w$ integracyjnych formach kształcenia przy jednoczesnym spadku liczby uczniów szkół specjalnych. Widać również, że edukacja integracyjna jest bardziej popularna na poziomie przedszkola oraz klas I-III szkół podstawowych, co może świadczyć o istnieniu skuteczniejszych rozwiązań stosowanych na pierwszych etapach edukacyjnych. Następnym aspektem była jakość usług edukacyjnych badana na podstawie wskaźnika obiektywnego, za jaki uznano obecność dodatkowego pedagoga i dostępność usług specjalistycznych w placówkach integracyjnych. W dalszej kolejności omówiono działalność różnych instytucji i organizacji promujących, podtrzymujących oraz rozwijających proces kształcenia integracyjnego. Uwzględniono przy tym funkcje i zadania gmin, powiatów, województw oraz innych jednostek publicznych związane z osobami z niepełnosprawnościami. Opisano również działalność najważniejszych organizacji pozarządowych funkcjonujących w poszczególnych regionach kraju. Przeprowadzone badania ukazują ogólne tendencje rozwoju szkolnictwa integracyjnego w Polsce oraz dostarczają materiału do porównań z innymi krajami. W końcowej części książki autorka podsumowała wyniki prac oraz sformułowała wnioski dla praktyki. Jej uwagi i postulaty są bardzo trafne. Autorka zaproponowała praktyczne rozwiązania istniejących problemów, warte wzięcia pod uwagę $\mathrm{w}$ procesie projektowania zmian. 
Ostatni rozdział został poświęcony osobie nauczyciela i jego roli w procesie edukacji uczniów z niepełnosprawnością w warunkach integracji. W tekście uwzględniono zadania zarówno pedagogów specjalnych, jak i tak zwanych nauczycieli "wiodących” oraz przedmiotowych. Autorka rozpatruje te kwestie $\mathrm{z}$ różnych perspektyw, bierze pod uwagę specyficzne i niespecyficzne kompetencje nauczycieli, ich predyspozycje osobowościowe, wiedzę, postawy. Podejmuje również wątek kształcenia pedagogów dla potrzeb edukacji integracyjnej z uwzględnieniem możliwości rozwoju zawodowego oraz instytucji prowadzących studia w tym zakresie.

Jak widać, zakres omawianego opracowania jest niezwykle szeroki. Poruszono w nim wiele wątków składających się na niemal kompletny obraz polskiego kształcenia integracyjnego na przestrzeni lat 1989-2012. Ze względu na bardzo szeroką analizę teoretyczną różnych aspektów związanych z pedagogiką specjalną publikacja ta może być traktowana nawet jako podręcznik akademicki. Jako że nie opracowano jeszcze solidnych podstaw teoretycznych pedagogiki integracyjnej, a wiedza naukowa na ten temat jest dość fragmentaryczna, pozycja autorstwa Danuty Apanel, stanowiąca bardzo wartościowe kompendium w tym zakresie, zdecydowanie może zostać polecona wszystkim osobom zainteresowanym kształceniem integracyjnym.

\section{Bibliografia}

APANEL D., Teoria i praktyka kształcenia integracyjnego w Polsce w latach 1989-2012, Wydawnictwo Adam Marszałek, Torun 2014. 